\title{
ANALYSIS OF PHYSIOLOGICAL AND SPECTRAL PARAMETERS ON DIFFERENT ORYZA SATIVA L. VARIETIES UNDER IRON STRESS
}

\author{
Banhishikha SINGH ${ }^{1}$, Rajeshwari CHATTERJEE ${ }^{2}$, Niniva DATTA ${ }^{1}$, Soma BANERJEE ${ }^{1}$ \\ ${ }^{1}$ Department of Biotechnology, Heritage Institute of Technology, 700107 Kolkata, India \\ ${ }^{2}$ Department of Hotel Management and Catering Technology, Birla Institute of Technology, Mesra, Ranchi, \\ 835215 Jharkhand, India \\ e-mail: soma.banerjee@ heritageit.edu
}

\begin{abstract}
Iron toxicity is an abiotic stress that comes with high concentrations of $\mathrm{Fe}^{2+}$ in the soil solution, and which is a well-recognized problem of rice (Oryza sativa L.) cultivation in the lowlands. Rice varieties differ widely in their ability to tolerate excess iron. The present study was undertaken with four rice varieties, viz. Dhruba, Sampriti, Dhiren and Puspa. The objective was to study the influence of applied high $\mathrm{Fe}^{2+}$ concentrations on the growth, chlorophyll content and antioxidant enzyme activities on these varieties of rice. The spectral reflectivity and absorption of different chemical bonding through Fourier-transform infrared spectroscopy (FTIR) of the four rice varieties were also analyzed. The 7-day-old rice seedlings were treated with ferrous sulfate and subjected to 100-750 ppm for a further 14 days. Iron stress was used to analyze the morphological and biochemical responses. At the same time, the root and shoot parts were exposed to the Fourier transform infrared spectral reflection. The results indicated that the shoot growth and chlorophyll content decreased by $750 \mathrm{ppm}$ in all the selected rice varieties of interest. On the contrary, the catalase activity, protein content, and lipid peroxidation increased in these varieties. However, a high amount of CAT activity in the Sampriti variety, and high amount of SOD activity in the Dhruba variety, led to a higher tolerance of iron stress, in comparison to the other two varieties studied. FTIR revealed steep band stretching of various functional groups of different compounds in both the root and shoot parts of all the varieties. The results revealed that the change of antioxidant expression and FTIR spectra were attributed to the effect of iron toxicity on rice plants.
\end{abstract}

Keywords: rice, Iron toxicity, chlorophyll, antioxidant, fourier transform infrared spectroscopy.

\section{Introduction}

Iron $(\mathrm{Fe})$ is one of the essential micro-elements, which is involved in several biological processes of plant cells throughout their lives. Due to the redox status change between the two states of iron, i.e. ferrous (Fe-II) and ferric (Fe-III), Fe acts as an electron donor or acceptor, which is vital for both photosynthesis and respiration [35, 58]. Moreover, in the case of plant growth, $\mathrm{Fe}$ enhances enzymatic redox reaction [24]. It also serves as a co-factor of several enzymes and is the major ingredient of the cell redox systems such as heme proteins, cytochrome, catalase (CAT), and peroxidase, and also FeS proteins, including ferredoxin, aconitase and superoxide dismutase isoenzyme (Fe-SOD) [41].

Lowland rice often suffers from Fe toxicity, which affects the yield [6] due to the excess amount of water-soluble Fe. Mineral soils, including acid clay, acid sulphate and peat soils [15], contain a high amount of Fe. The interflow of water increases the Fe content in the fields of lowland rice. [50]. Under the flooded conditions, the microbial reduction of insoluble Fe (III) into soluble Fe (II), results in excess Fe in lowland soil [48]. The nutrient imbalance in plants is created due to the indirect effects of excess Fe, through the reduction of uptake and utilization of essential 
nutrients (phosphorus, potassium, calcium, magnesium, and zinc) in plants [19].

Excessive Fe absorption by plants generates a symptom called 'bronzing'. The roots of rice plants affected by Fe toxicity become shorter in length and dark brown in colour, resulting in underdeveloped root and shoot growth [17], as well as inhibition of nutrient uptake [59]. The toxicity is generated by donating or accepting an electron from the surrounding biomolecules with excess $\mathrm{Fe}$, which produces reactive oxygen species (ROS), thus causing major damage to the cellular components. In tissue, Fe catalyzes the ROS formation via the Fe catalyzed Haber-Weiss reaction (Fenton reaction), in the presence of ascorbate or hydrogen peroxide $\left(\mathrm{H}_{2} \mathrm{O}_{2}\right)$, resulting in the generation of hydroxyl radicals [26]. Plants show different systems of tolerance to Fe toxicity [7], including shoot-based tolerance mechanism, i.e. the scavenging of ROS by antioxidants like ascorbate, phenolics, glutathione, ascorbate peroxidase (APX), SOD [20, 39]. Similarly, CAT also plays a role in plant-tolerance to Fe toxicity [55]. The phenolic compounds are generally capable of scavenging hydroxyl and lipid radicals [12].

The present report emphasizes the effect of Fe toxicity on the rice seedlings, the mechanisms of its tolerance in seedling growth, and biochemical parameters, i.e. chlorophyll content, antioxidant enzyme activities which include SOD, CAT activity and lipid peroxidation, in four rice varieties, viz. Dhruba, Sampriti, Dhiren and Puspa. The spectral analysis of Fourier transform infrared spectroscopy (FTIR) has been performed for analyzing spectral reflectivity and absorption of different chemical bondings, as well as for studying the conformational changing of functional groups of carbohydrates, proteins and lipids [31, 42, 52, 53, 56]. Using this fast method, the initial spectral response to Fe toxicity can be examined by comparing the fingerprints of the global cellular features from very small amounts of samples $[3,5,14]$.

The novelty of this study lies in finding the Fe toxicity tolerant variety among the four rice varieties Dhruba, Sampriti, Dhiren and Puspa, which are locally cultivable in the lowland areas of West Bengal, with respect to its physiological and FTIR spectral study.

\section{Materials and Methods}

\section{Plant material and experimental design}

According to Green and Etherington (1977), after flooding, the $\mathrm{Fe}^{2+}$ iron concentration of the soil solution increases sharply up to $500 \mathrm{ppm}$. Hence, Fe stresses were given to the different varieties of rice seeds in sterilized Petri-dishes at the germination period, in order to check the tolerance level of Fe stress at different concentrations on the different rice varieties. $50 \%$ of the lethal dose was found at $750 \mathrm{ppm}$. Seeds of the four different varieties of rice (Oryza sativa L.), viz. Dhruba, Sampriti, Dhiren and Puspa, were collected from Bankura Rice Research Station, West Bengal. Rice seedlings were cultured under the following conditions: 1000 lux light intensity for 16 hours with the interval of 8 hours, $29 \pm 2{ }^{\circ} \mathrm{C}$ temperature, and $60 \pm 5 \%$ relative humidity with 'Yoshida solution' [57], for 21 days. Bremen and Moormann (1978) reported that Fe solubility in water-flooded soil and Fe uptake by plants is related to a $\mathrm{pH}$ below 5.8. Therefore, the $\mathrm{pH}$ of the media was maintained between 5.3 to 5.9 .

The treatments comprised exposure of the seedlings to $\mathrm{FeSO}_{4} \cdot 7 \mathrm{H}_{2} \mathrm{O}$ solution at five different concentrations, viz. 0 (control), 100, 250, 500, $750 \mathrm{ppm}$, after the plants attained the age of 7 days, for a continuous 14-day duration. The lengths of both the roots and the shoots of the growing rice seedlings were measured. 


\section{Estimation of Chlorophyll contents}

Chlorophyll contents were measured through extraction with $80 \%$ acetone, according to Arnon (1949). Since rice is a monocot plant, therefore the whole shoot part was taken for chlorophyll estimation. The following equation was used to calculate total chlorophyll, and the chlorophyll content was expressed on a fresh weight (FW) basis.

Chlorophyll A: 12.7 ( $\left.\mathrm{A}_{663}\right)-2.69\left(\mathrm{~A}_{645}\right)$

Chlorophyll B: 22.9( $\left.\mathrm{A}_{645}\right)$ - 4.68( $\left.\mathrm{A}_{663}\right)$

Estimation of soluble protein content and antioxidant activity

Soluble protein was estimated by the method of Bradford (1976). The whole shoot part and all the rootlets were taken separately for the estimation of protein content. Ice-chilled plant materials were used for the experiment. Plant material was extracted with $0.1 \mathrm{M}$ phosphate buffer $\mathrm{pH}=6.8$, as mentioned by Kar and Mishra (1976), for the estimation of protein content, CAT activity and SOD activity.

CAT activity was measured in a spectrophotometer at room temperature, by monitoring the decrease in absorbance at $240 \mathrm{~nm}$ resulting from $\mathrm{H}_{2} \mathrm{O}_{2}$ decomposition [1]. One unit (U) of CAT was equivalent to the change of absorbance at the rate of 0.001 per minute in the presence of CAT. The reaction mixture contained $100 \mathrm{mM}$ sodium phosphate buffer $(\mathrm{pH} 7.0), 30 \mathrm{mM} \mathrm{H}_{2} \mathrm{O}_{2}$, and 100 $\mu \mathrm{L}$ of crude extract in a total volume of $3.0 \mathrm{~mL}$.

SOD activity was determined by the method based on the performance of the enzyme for the inhibition of pyrogallol autoxidation [38]. One unit (U) of SOD activity is defined as the amount of enzyme required to inhibit $50 \%$ of pyrogallol autoxidation [40].

The rate of lipid peroxidation was estimated by the method of Heath and Packer (1968) and calculated as the amount of malondialdehyde produced. The tissue was boiled with thiobarbituric acid reagent $(0.25 \%$ TBA in $10 \%$ TCA). The mixture was at first cooled, and then centrifuged at 10,000X g for $10 \mathrm{~min}$. The absorbance was recorded at $440 \mathrm{~nm}, 532 \mathrm{~nm}$ and $600 \mathrm{~nm}$ $[30,36]$. To maintain the accuracy of determining malondialdehyde content the calculation was done in the following manner:

$$
\begin{aligned}
& {\left[\left(\mathrm{A}_{532}\right)-\left(\mathrm{A}_{600}\right)\right]=\mathrm{A}} \\
& {\left[\left(\mathrm{A}_{440}-\mathrm{A}_{600}\right) 0.0571\right]=\mathrm{B}}
\end{aligned}
$$

Malondialdehyde content: (A-B/0.157)

Fourier transform infrared spectroscopy-attenuated total reflection (FTIR-ATR)

The FTIR-ATR spectra of rice samples were recorded with an FTIR spectrometer with a germanium-coated potassium bromide $(\mathrm{KBr})$ plate and an attached ATR unit in the range of 4000$500 \mathrm{~cm}^{-1}$ (Shimadzu Corpn., Japan, IR-Prestige-21). Solutions were prepared using MilliQ deionized water.

\section{Statistical analysis}

The average of five sets of repetitive measurements was taken from each experiment, each one further repeated five times, with randomly chosen samples. All the collected data were analyzed using Analysis of Variance (ANOVA) by SPSS version 20. The statistical analysis was conducted for testing the significance of the stress effect. Duncan Multiple Range test was carried out according to the least significant difference (LSD) values. Standard methods have been used to calculate F-test and critical difference [45]. All the statistical tests were analyzed at 5\% of a significant level. 


\section{Results}

Effect of Fe toxicity on growth parameters of rice seedlings

The shoot-length of all the rice varieties showed different growth in Fe stress. The Dhiren variety showed a marked decrease in shoot-length (31\%) at $750 \mathrm{ppm}$ of toxicity, in comparison to control-treatment (Fig. 1a). The Puspa, Dhruba and Sampriti varieties showed 11.5\%, 9\%, and 5\% decrease in shoot-growth respectively. The resultant shoot-length was significantly correlated with the $\mathrm{P}$-value $=0.002$. The root-length in Dhiren and Puspa decreased at $750 \mathrm{ppm}$ of Fe toxicity by $20 \%$ and $46 \%$, respectively (Fig. 1b). In contrast, the total root-length increased in the Dhruba and Sampriti varieties by $27 \%$ and $12 \%$ respectively. The data have a significant mean difference with the P-value $=0.000$.
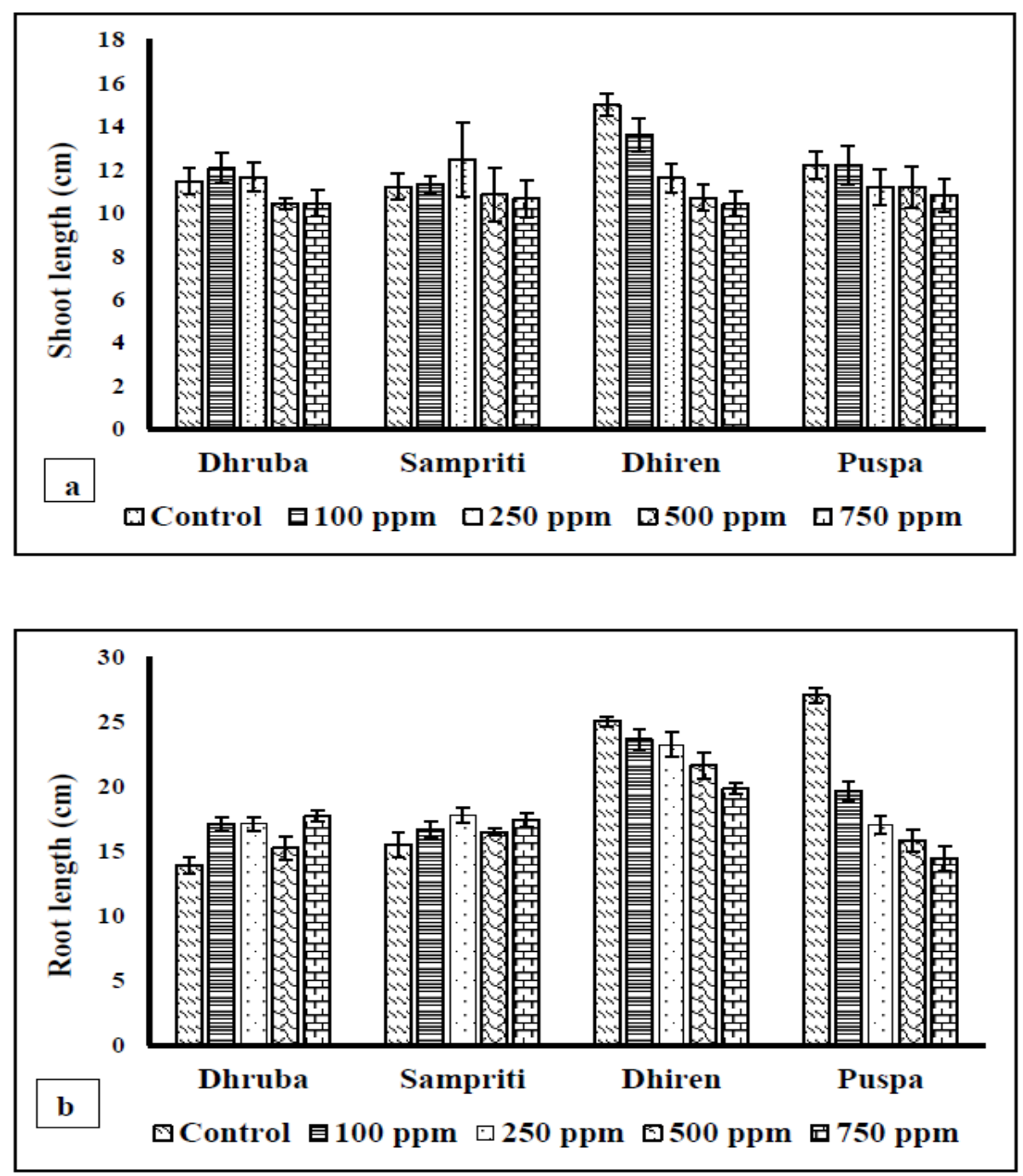

Fig. 1: Effect of iron stress on (a) shoot-length and (b) total root-length of different rice varieties (bars indicate mean values \pm (Standard Error) $S E, n=5$ ).

\section{Chlorophyll content in rice under Fe toxicity}

Chlorophyll contents in rice seedlings showed different responses to $\mathrm{Fe}$ stress. The chlorophyll A content decreased significantly in Dhruba by $61 \%$, followed by Puspa, Dhiren, and 
Sampriti by $60 \%, 48 \%$, and $31 \%$ at 750 ppm respectively, as compared to the control (Fig. $2 \mathrm{a}$ ). The result correlates significantly with the $\mathrm{P}$-value $=0.05$. The chlorophyll $\mathrm{B}$ content decreased significantly in Dhruba by $61 \%$, followed by Puspa, Dhiren, and Sampriti by $57 \%$ 48\%, and $17 \%$ at $750 \mathrm{ppm}$ respectively, as compared to the control (Fig. 2b). The resultant data have a significant mean difference with the $\mathrm{P}$-value $=0.000$.
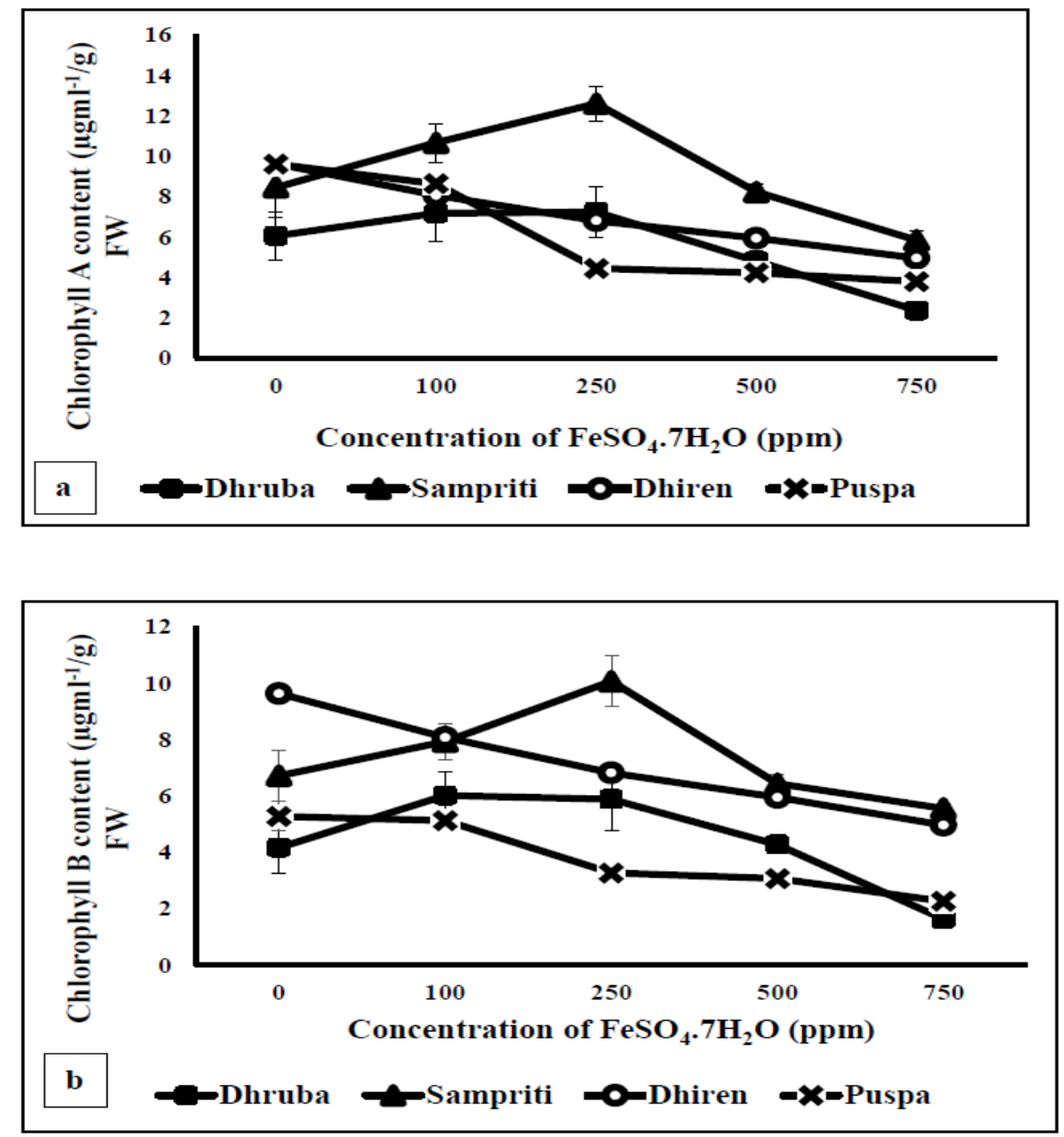

Fig. 2: Effect of iron stress on total chlorophyll content in rice seedlings (bars indicate mean values $\pm S E, n=5$ ).

\section{Protein content in rice to Fe toxicity}

The protein content in the shoot parts of the Dhruba, Sampriti and Puspa varieties of rice seedlings showed a slight increase $(6 \%, 9 \%$ and $5.6 \%$ respectively), while the Dhiren variety showed a slight decrease $(2.4 \%)$ in $750 \mathrm{ppm}$ of Fe stress as compared to the control (Fig. 3a). On the other hand, while the protein content in the root parts of the Dhruba and Sampriti varieties of rice seedlings showed a slight decrease (4\% and 3\% respectively), the Dhiren and Puspa varieties showed a slight increase (23\% and $8 \%$ respectively) in $750 \mathrm{ppm}$ of Fe stress as compared to the control (Fig. 3b). (P-value of ANOVA for both shoot protein and root protein was 0.000 ). 

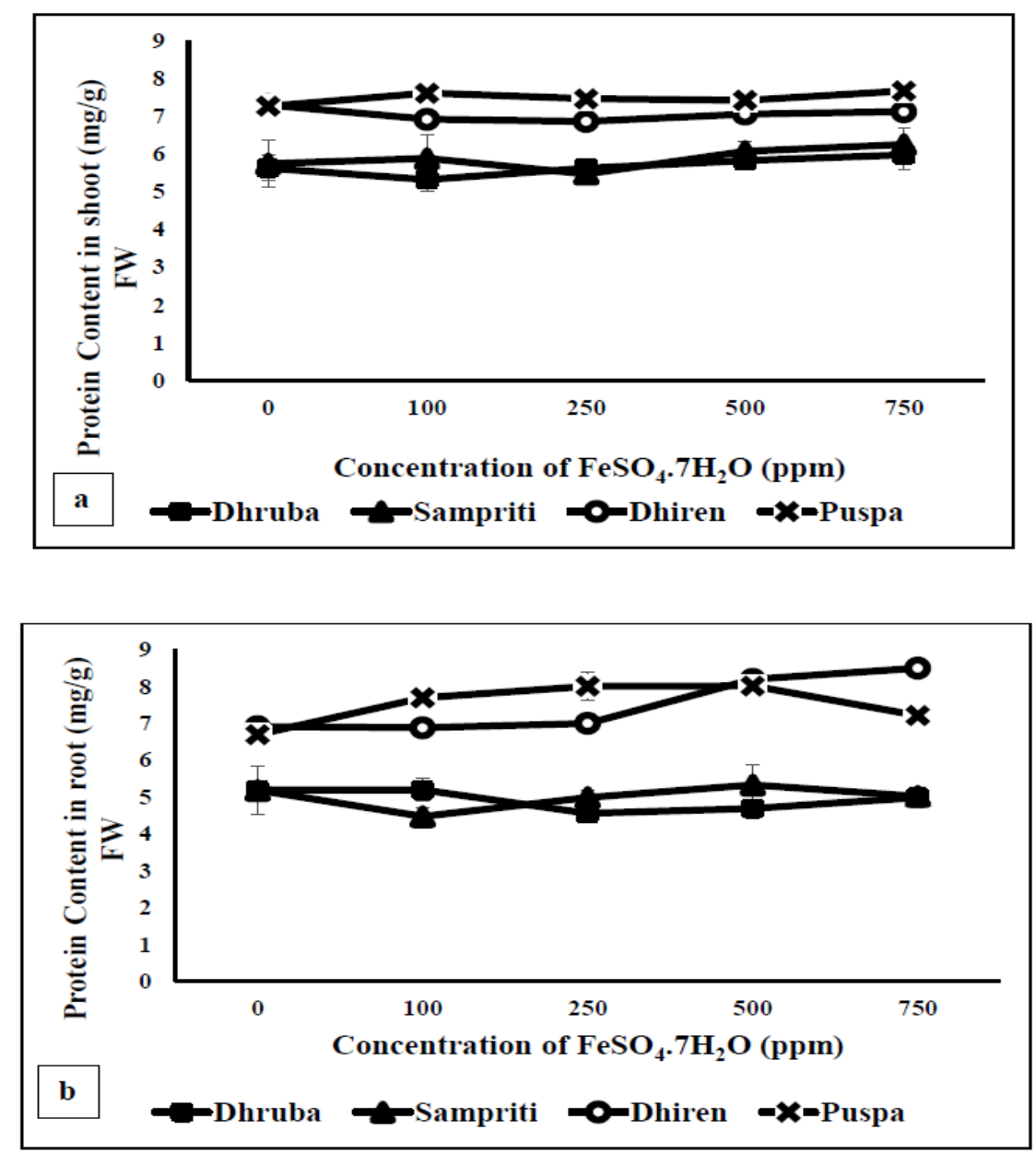

Fig. 3: Effect of iron stress on soluble protein content in rice seedlings (bars indicate, mean values $\pm \mathrm{SE}, \mathrm{n}=5)$.

\section{Superoxide Dismutase activity}

The SOD activity in the shoot parts of varieties Sampriti, Dhiren and Puspa was found to have decreased by $22.6 \%, 16 \%$, and $16 \%$ respectively. On the contrary, there was no significant difference in the Dhiren variety (Fig. 4a). But the activity in the roots of the Dhruba variety increased by $21 \%$, whereas in the Sampriti, Dhiren and Puspa varieties it decreased by $19 \%, 20 \%$, and $8 \%$ respectively (Fig. 4b). The result of SOD activity in the shoot-length proved to be statistically significant (P-value of ANOVA for SOD activity in the shoot was 0.003 and 100 ppm to $750 \mathrm{ppm}$ in the root was 0.0123 ).

\section{Catalase activity}

The CAT activity in the shoot parts of Dhruba, Sampriti, Dhiren and Puspa were found to have increased to $77 \%, 46 \%, 81 \%$ and $17 \%$ respectively (Fig. 5a). The CAT activity in the root parts of Dhruba, Sampriti, Dhiren, and Puspa were found to have increased to $95 \%, 147 \%, 11 \%$ and $74 \%$ respectively, as compared to the control (Fig. 5b). (P-value of ANOVA for CAT activity in both shoot and root was 0.000 ). 

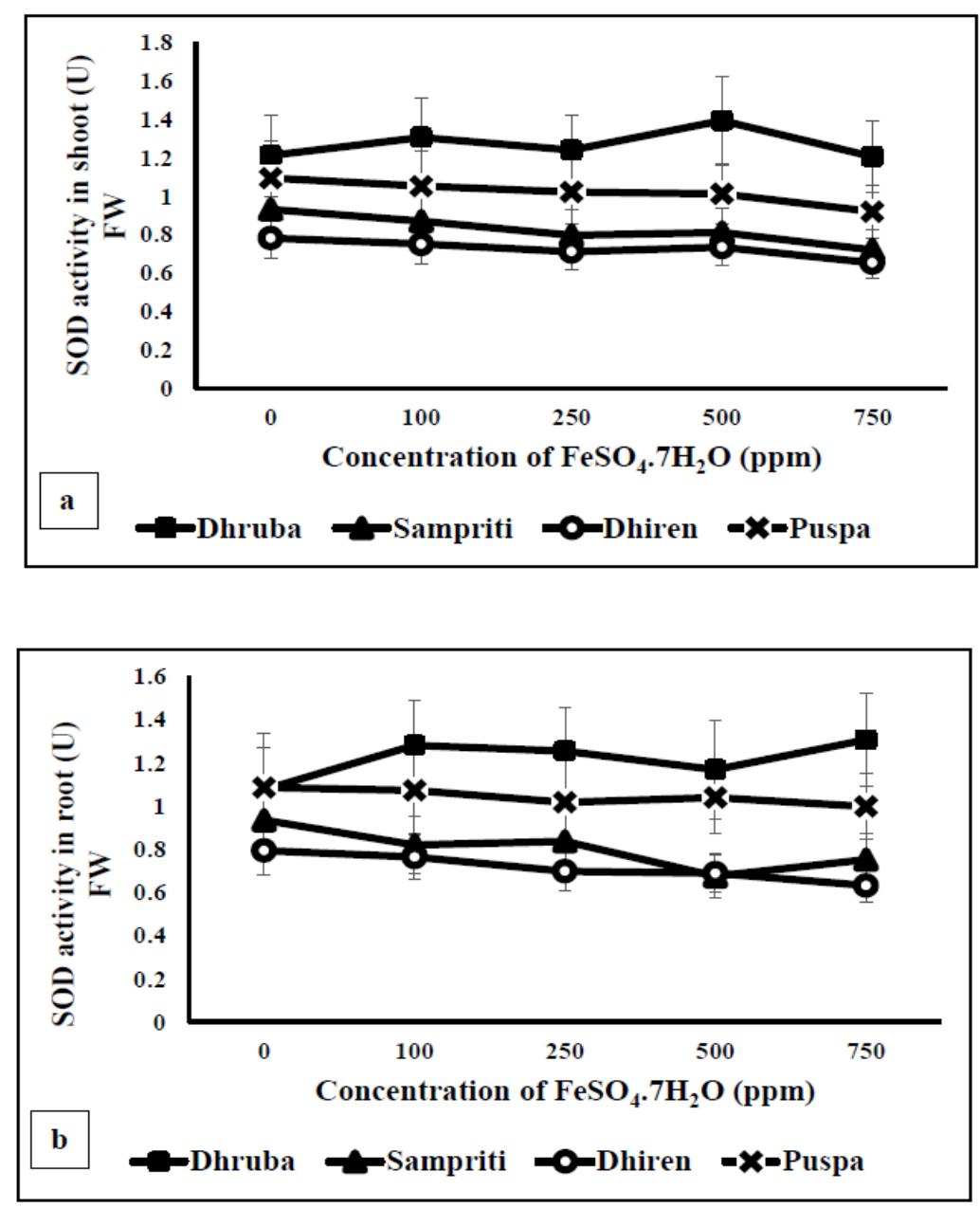

Fig. 4: Effect of iron stress on SOD activity in shoot (a) and root part (b) (mean values $\pm S E, n=5$ ).

\section{Lipid peroxidation}

The content of malondialdehyde (a by-product of lipid peroxidation) in the shoots of Dhruba, Sampriti, Dhiren, and Puspa, increased to 94\%, 26\%, 0.3\%, and 9\% respectively (Fig. 6a). The activity in the root-parts of Dhruba, Sampriti, Dhiren, and Puspa was found to have increased to $77 \%, 8 \%, 28 \%$, and 35\% respectively, as compared to control (Fig. 6b). (P-value of ANOVA for lipid peroxidation in the shoot was 0.000 and for lipid peroxidation in root was 0.000 ).

FTIR analysis to monitor the changes in seedlings under iron toxicity

In the FTIR spectrum, the infrared radiation peak values have been used to identify the functional group present in the active components based on the regions. This technique was useful for the study of the conformational changes in carbohydrate, lipid, protein and cell wall components among the experimental set of all the four rice varieties, between the control sample and the sample treated with $750 \mathrm{ppm}$ of $\mathrm{FeSO}_{4} \cdot 7 \mathrm{H}_{2} \mathrm{O}$. The changes in the absorption band at 3400 $\mathrm{cm}^{-1}$ represent the $\mathrm{O}-\mathrm{H}$ and $\mathrm{N}-\mathrm{H}$ stretching vibrations that occur in carbohydrate and protein and that was observed in root and shoot parts of all the four varieties (Fig 7 a-d) [18]. An interesting peak change around $2800 \mathrm{~cm}^{-1}$ to $3000 \mathrm{~cm}^{-1}$ represents $\mathrm{C}-\mathrm{H}$ stretching, $\mathrm{CH}_{2}$ and $\mathrm{CH}_{3}$ alkyl chains, and olefinic bonds in the lipid region [8, 32]. Again, the band change at $2960 \mathrm{~cm}^{-1}$ was due to an antioxidant effect of phenolic acids, observed in the root and shoot parts of Dhruba, Sampriti and 
Puspa (Fig.7 a,b,d). Absorption band change at $1745 \mathrm{~cm}^{-1}$ was found in the shoot part of the varieties Dhruba, Sampriti and Puspa. It is due to the ketone stretching in ester-containing compounds, diketone, and acid anhydrides and -COOR bonds in the membrane lipid and cell wall pectin [47]. The changes in protein absorption bands $\sim 1680 \mathrm{~cm}^{-1}$ (amide I band) observed in the shoot parts of all varieties are due to $\mathrm{C}-\mathrm{O}$ bond bending in proteins [5, 53]. Again, amide II band change in the root and shoot parts of all varieties at $\sim 1550 \mathrm{~cm}^{-1}$ is due to N-H bond stretching observed in both the root and shoot part of all the four rice varieties [5]. The amide III band change at $\sim 1250 \mathrm{~cm}^{-1}$ was due to $\mathrm{C}-\mathrm{N}$ stretching in proteins and $\mathrm{C}-\mathrm{O}$ asymmetric stretching in cyclic polyphenolic compounds observed in the root-parts of Sampriti, Dhiren and Puspa and shoot part of Dhruba, Sampriti. Significant absorbance band change was seen at $1630 \mathrm{~cm}^{-1}$, is corresponded to an antioxidant effect due to $\mathrm{H}_{2} \mathrm{O}_{2}$-induced protein aggregation [39], which is increased shootpart of Puspa and Sampriti and root-part of Dhruba. Acid band change at $1420 \mathrm{~cm}^{-1}$ is related to the COO- stretching; due to the $\mathrm{Fe}^{+}$absorption observed in the shoot and root parts of all the varieties [33]. Bands around $1000 \mathrm{~cm}^{-1}$ to $1100 \mathrm{~cm}^{-1}$ in the "fingerprint" region indicate several modes such as $\mathrm{C}-\mathrm{H}$ bending or $\mathrm{C}-\mathrm{O}$ or $\mathrm{C}-\mathrm{C}$ stretching of carbohydrates indicating significant vibration in the shoot parts of all the varieties [5]. Changes in the band at $1050 \mathrm{~cm}^{-1}$ in all the root and shoot parts of all the varieties were attributed to iron-oxyhydroxide. The strong band changes in all the varieties were observed at $450 \mathrm{~cm}^{-1}$ to $500 \mathrm{~cm}^{-1}$ (Fig 7a-d) both in the shoot and root parts, attributed to Fe-O bond stretch [43, 44].
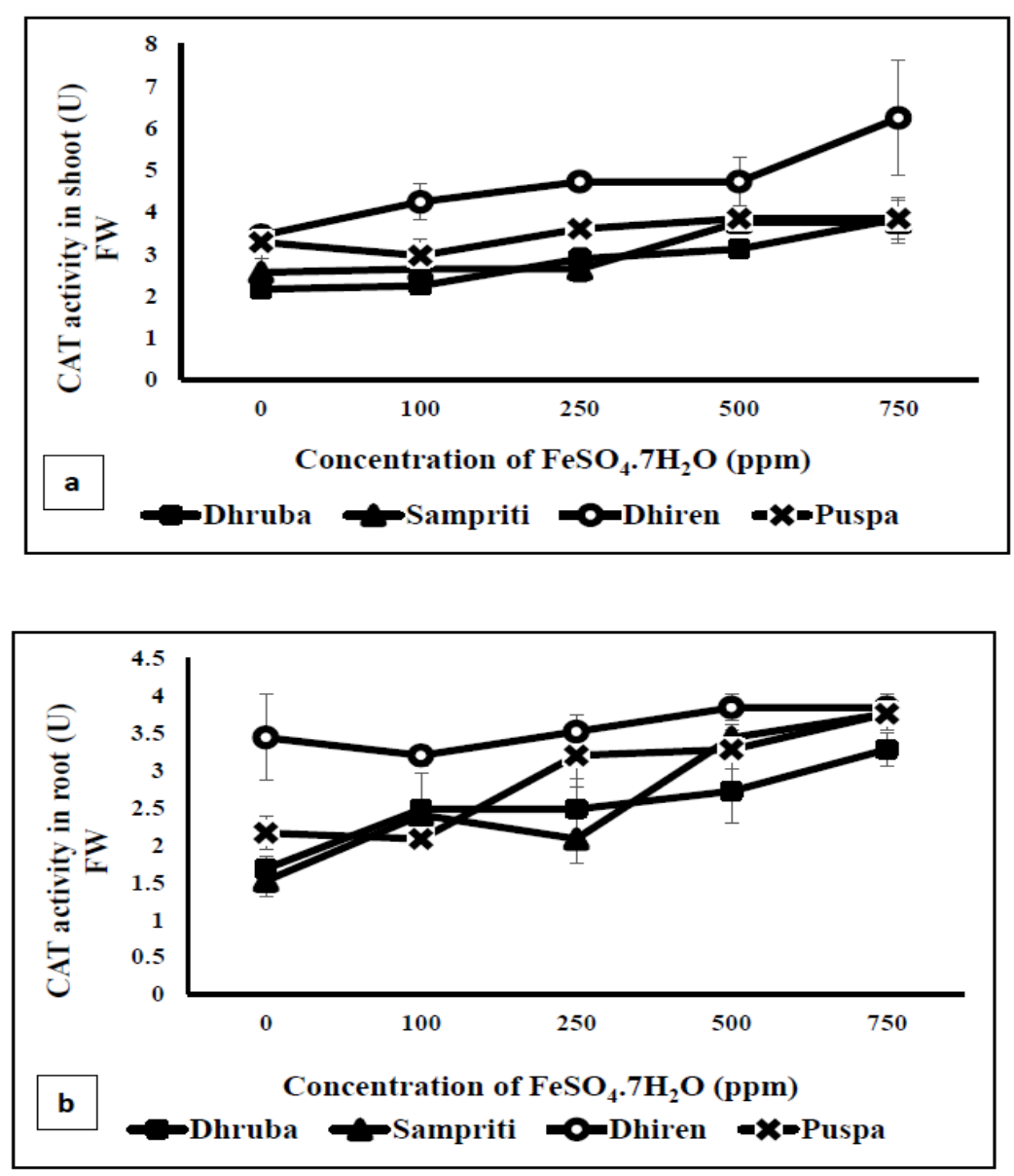

Fig. 5: Effect of iron stress on CAT activity in shoot (a) and root (b) part (mean values $\pm \mathrm{SE}, \mathrm{n}=5$ ). 

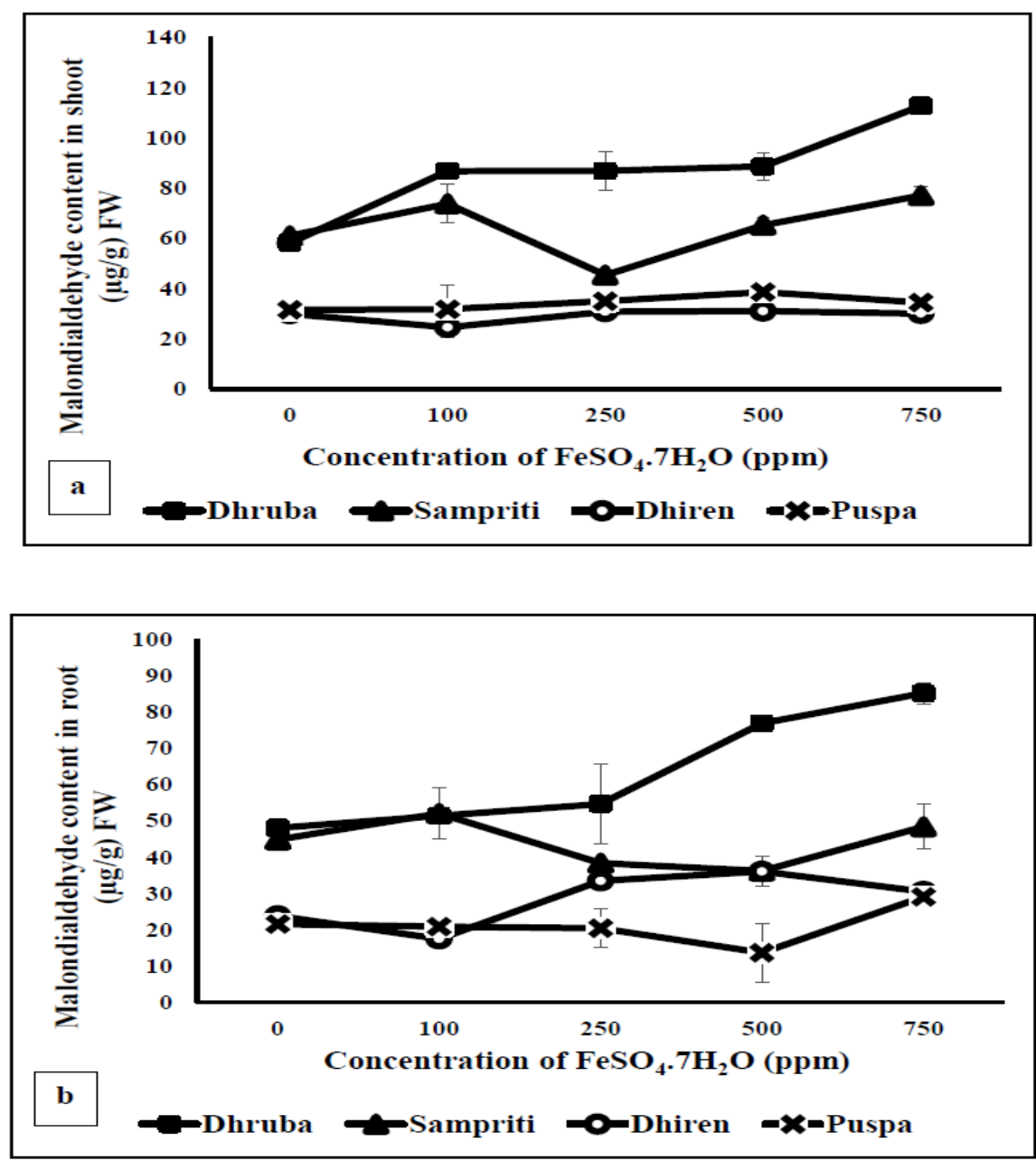

Fig. 6: Effect of iron stress on lipid peroxidation in shoot part (a) (bars indicate, mean values and root part (b) (bars indicate, mean values $\pm S E, n=5$ ).

\section{Discussion}

Growth of all the rice varieties decreased under high concentrations of Fe; Dhiren and Puspa varieties showed significant growth reduction among the four rice varieties. A similar result is reported by Gangarani et al. (2018) and Pereira et al. (2013). Excess of water-soluble Fe present in the flooded situation leads to translocation into plant cells, causing oxidative damage within the cells [49]. Plant pigments like chlorophyll are susceptible to ROS and found to be affected by oxidative stress induced by $\mathrm{Fe}[37,51,54]$, resulting in chlorophyll degradation and non-stomatal limitation of photosynthesis. The decrease in chlorophyll A and chlorophyll B content varied differently between tolerant and non-tolerant varieties. In Sampriti and Dhruba at $250 \mathrm{ppm}$ chlorophyll (A and B) content increased and decreased from 500 ppm, whereas in other varieties chlorophyll (A and B) content decreased from $250 \mathrm{ppm}$. Excess induced Fe stress reduced ROS resulting in breakage of chlorophyll pigment. The reduced chlorophyll content is one of the reasons that reduces shoot growth through a reduction in the photosynthetic carbon assimilation rate [21].

The SOD activity of the Sampriti, Dhruba, and Puspa varieties decreased very nominally under Fe stress. However, in all the rice varieties CAT activity increased significantly. A similar result observed in the findings of Gao et al. (2014) was that under $250 \mathrm{mg} / \mathrm{L} \mathrm{Fe}$ stress, the SOD 
activity of the rice genotypes decreased. Xing et al. (2010) and Hendry and Brocklebank (1985) have revealed that CAT activity is important in the plant resistance to Fe toxicity, through interaction with ROS $\left(\mathrm{H}_{2} \mathrm{O}_{2}\right)$ generated by Fenton Reaction. A significant increase was found in the lipid peroxidation rate in both the root as well as the shoot parts of all the rice varieties, under Fe toxicity. Production of ROS might be increased parallelly with increased lipid peroxidation under this stress. This may result in the formation of malondialdehyde, one of the two final products of peroxidation of unsaturated fatty acids in phospholipids, and that occurred due to cell membrane damage, as indicated by Halliwell and Gutteridge (2015). Further, the FTIR spectral analysis confirms the presence of phenolic compounds that may scavenge the ROS and hydroxy radicals which are also generated by Fenton reaction.

FTIR spectra for Fe toxicity in all the varieties show the presence of steep band stretching of various functional groups of different compounds. Potential protein structural and chemical compositional changes that occur during abiotic stress, like Fe toxicity due to protein and carbohydrates and also $\mathrm{Fe}^{+}$cationic interaction with the hydroxyl group for metal-oxygen binding [18] was seen in Dhruba, Samprity and Puspa varieties at $3400 \mathrm{~cm}^{-1}$.

The IR spectra value changes between $2960-3012 \mathrm{~cm}^{-1}$ were seen in all the four rice varieties due to lipid desaturation compiled with antioxidant activity of phenolic compounds [8, 32].

The spectral peak change at $1745 \mathrm{~cm}^{-1}$ were evidence of lipid peroxidation (malondialdehyde formation) $[9,13,47]$. The same peak was found in the experimental data of lipid peroxidation with the four rice varieties.

Another two absorption regions which could be marked as key indicators of stress levels and metabolic status are amide I at $1645-1680 \mathrm{~cm}^{-1}$, and amide II bands at $1550 \mathrm{~cm}^{-1}$. The study reveals that a minor change in the band intensity is the major factor that causes an oxidative stressinduced change in the secondary structure of a cellular protein. An amino acid chain consists of tyrosine, histidine, glutamic acid, glutamine, asparagine and arginine [56]. The peak changes at $1630 \mathrm{~cm}^{-1}$ in all the four rice varieties correspond to an antioxidant effect [39] and the peak change at $1240 \mathrm{~cm}^{-1}$ is related to the iron toxicity in plants.

The decrease in spectral range in the peak of the stressed set at $1000-1100 \mathrm{~cm}^{-1}$ in the 'fingerprint' region indicates specially xyloglucan due to the interaction with the ironoxyhydroxide [33]. Iron-oxyhydroxide can also destroy the photosynthesis and can disturb the plant hormone and iron balance, corresponding to the iron-oxyhydroxide phase; further, the changes in the bands at $433-477 \mathrm{~cm}^{-1}$ also indicate $\mathrm{Fe}-\mathrm{O}$ bond stretch, found in all the four rice varieties. [43, 44].

Several researchers like Alscher et al. (1997) and Dionisio-Sese and S. Tobita (1998) had demonstrated that an increase in ROS-scavenging capacity through antioxidant enzyme resulted in improvement in stress tolerance of plants. Our results show that a significant increase in CAT activity, protein aggregation with amide I and II bands, and the presence of phenolic compounds are responsible for the toxicity tolerance in the Sampriti variety. 

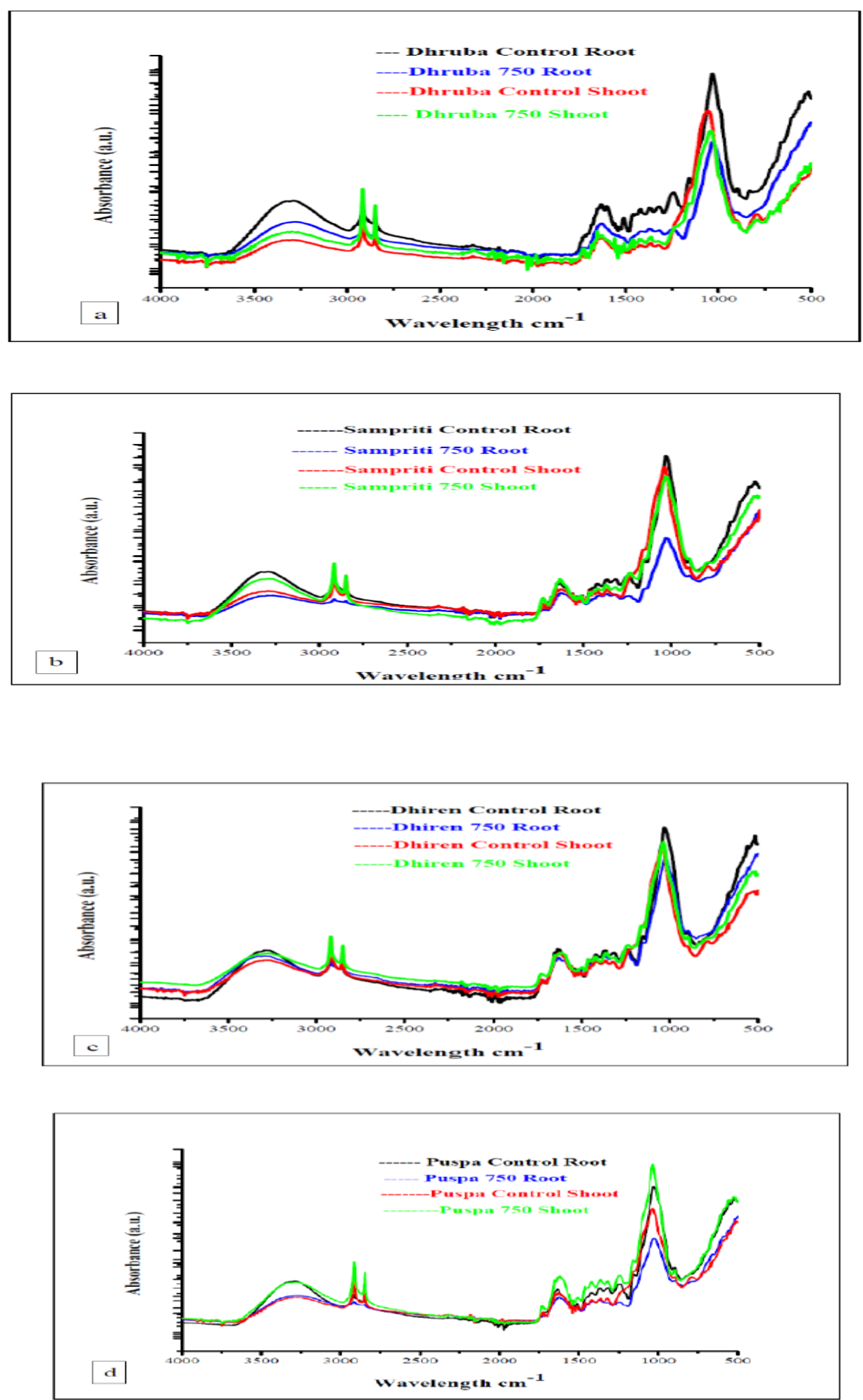

Fig. 7: FTIR spectra curves of shoot and root parts of Dhruba (a), Sampriti (b), Dhiren (c) and Puspa (d) rice varieties under $750 \mathrm{ppm}$ against the control. 
This work concludes that an increase in lipid peroxidation is the primary response of Fe toxicity, and the decrease in chlorophyll content is a part of the overall expression of Fe toxicity. Analysis of FTIR spectra for Fe toxicity in four rice varieties shows the steep band stretching of various functional groups, which is an evidence of structural modification of lipid, protein, and carbohydrates, in both root part and shoot part of the all the four rice varieties. A high amount of CAT activity in Sampriti may lead to reduce lipid peroxidation in the root part, resulting in increased root-length in the stress condition. The decrease in amide I and amide II band peaks are related to the sensitivity of the Dhiren variety, and the increase in those bands corresponds to the tolerance of the Sampriti variety, through the formation of antioxidant enzymes and phenolic compounds. Therefore, the effects of Fe toxicity on the growth as well as other physiological expressions of rice plants are influenced by both variety and the concentration of Fe to which the plant is exposed.

Acknowledgement: This work has supported by University Grant Commission-Maulana Azad National Fellowship. We are also thankful to the Central Instrument Facility of Birla Institute of Technology, Mesra, Ranchi, India, for providing facilities to carry out the present work. The authors would like to acknowledge the Rice Research Station, Bankura for providing the rice samples. They wish to acknowledge the authorities of the Heritage Institute of Technology for providing necessary technical and infrastructural support for this work.

Conflict of interest: None declared.

\section{REFERENCES}

1. Aebi, H.E., 1983, Catalase. In: Bergmeyer, H.U. (Ed.), Methods of enzymatic analysis, Verlag Chemie Weinheim: 273-286. doi:10.1016/b978-0-12-091302-2.50032-3

2. Alscher, R.G., Donahue, J.L., Cramer, C. L., 1997, Reactive oxygen species and antioxidants: relationships in green cells, Physiologia Plantarum, 100 (2): 224-233. doi:10.1111/j.1399-3054.1997.tb04778.x

3. Alvarez-Ord'onnez, A., Halisch, J., Prieto, M., 2010, Changes in Fourier transform infrared spectra of Salmonella enterica serovars Typhimurium and Enteritidis after adaptation to stressful growth conditions, International Journal of Food Microbiology, 142 (1-2): 97-105. doi:10.1016/j.ijfoodmicro.2010.06.008

4. Arnon, D.I., 1949, Copper enzymes in isolated chloroplasts. Polyphenoloxidase in Beta vulgaris, Plant Physiology, 24 (1):1-15. doi:10.1104/pp.24.1.1

5. Barth, A., 2000, The infrared absorption of amino acid side chains, Progress in Biophysics \& Molecular Biology, 74: 141-173. doi:10.1016/s0079-6107(00)00021-3

6. Baruah, K.K., Das, S., Das, K., 2007, Physiological disorder of rice associated with high levels of iron in growth medium, Journal of Plant Nutrition, 30 (11): 1871-1883. doi:10.1080/01904160701629096

7. Becker, M, Asch, F., 2005, Iron toxicity in rice-conditions and management concepts, Journal of Plant Nutrition and Soil Science, 168: 558-573. doi:10.1002/jpln.200520504

8. Bellisola, G., Sorio, C., 2012, Infrared spectroscopy and microscopy in cancer research and diagnosis, American Journal of Cancer Research, 2 (1):1-21.

9. Benseny-Cases, N., Klementieva, O., Cotte, M., Ferrer, I., Cladera, J., 2014, Microspectroscopy ( $\mu$ FTIR) reveals co-localization of lipid oxidation and amyloid plaques in human Alzheimer disease brains, Analytical Chemistry, 86 (24):12047-12054. doi: 10.1021/ac502667b

10. Bradford, M.M., 1976, A rapid and sensitive method for the quantitation of microgram quantities of protein utilizing the principle of protein-dye binding, Analytical Biochemistry, 72: 248-254. doi:10.1016/00032697(76)90527-3 
11. Bremen, N.V., Moormann, F. R., 1978, Iron toxic soils. In Soils and Rice, Ed. IRRI, 781-800 [Los Banos, Philippines: IRRI].

12. Chimi, H., Morel, I., Lescoat, G., Pasdeloup, N., Cillard, P., Cillard, J., 1995, Inhibition of iron toxicity in rat hepatocyte culture by natural phenolic compounds, Toxicology in Vitro, 9 (5): 695-702. doi:10.1016/08872333(95)00060-1

13. Chwiej, J., Dulinska, J., Janeczko, K., Dumas, P., Eichert, D., Dudala, J., Setkowicz, Z., 2010, Synchrotron FTIR micro-spectroscopy study of the rat hippocampal formation after pilocarpine-evoked seizures, Journal of Chemical Neuroanatomy, 40 (2):140-147. doi: 10.1016/j.jchemneu.2010.03.008.

14. Corte, L., Rellini, P., Roscini, L., Fatichenti, F., Cardinali, G., 2010, Development of a novel, FTIR (Fourier transform infrared spectroscopy) based, yeast bioassay for toxicity testing and stress response study, Analytica Chimica Acta, $\mathbf{6 5 9}$ (1-2): 258-265.

15. Deturck, P., 1994, Iron toxicity to rainfed lowland rice in Sri Lanka. [KULFLTB, Leuven, Belgium].

16. Dionisio-Sese, M.L., Tobita, S., 1998, Antioxidant responses of rice seedlings to salinity stress," Plant Science, 135(1): 1-9.

17. Dorlodot, S., Lutts, S., Bertin, P., 2005, Effects of ferrous iron toxicity on the growth and mineral composition of an interspecific rice, Journal of Plant Nutrition, 28: 1-20. doi: 10.1081/PLN-200042144.

18. D’Souza, L., Devi, P., Divya Shridhar, M., Naik, C.G., 2008, Use of Fourier Transform Infrared (FTIR) spectroscopy to study cadmium induced changes in Padina tetrastromatica (Hauck), Anal. Chem. Insights 3, 117739010800300001.

19. Fageria, N.K., Santos, A.B., Barbosa Filho, M.P., Guimarães, C.M., 2008, Iron Toxicity in Lowland Rice, Journal of Plant Nutrition, 31: 1676-1697, doi: 10.1080/01904160802244902.

20. Fang, W.C., Wang, J.W., Lin, C.C, Kao, C.H., 2001, Iron induction of lipid peroxidation and effects on antioxidative enzyme activities in rice leaves, Plant Growth Regulation, 35: 75-80. doi:10.1023/A:1013879019368

21. Fukuda, A., Terao, T., 2015, QTLs for Shoot-length and Chlorophyll Content of Rice Seedlings Grown under Low-Temperature Conditions, using a Cross between Indica and Japonica Cultivars, Plant Production Science, 18 (2): 128-136, doi:10.1626/pps.18.128.

22. Gangarani, A., Rangappa, K., Yadav, G., Lembisana Devi, H., Barman, K., Kandpal, B. Ngachan, S.V., 2018, Physiological Tolerance Mechanism of selected Rice Germplasm of Northeast India to Iron Toxicity, Indian Journal of Hill Farming, 31 (1): 75-81.

23. Gao, P.P., Zheng, G.H., Wu, Y.H, Liu, P., 2014, Effect of Exogenous Potassium on Photosynthesis and Antioxidant Enzymes of Rice under Iron Toxicity, Russian Journal of Plant Physiology, 61 (1): 47-52. doi:10.1134/S1021443714010051.

24. Gill, S.S, Tuteja, N., 2010, Reactive oxygen species and antioxidant machinery in abiotic stress tolerance in crop plants, Plant Physiology and Biochemistry, 48: 909-930. doi:10.1016/j.plaphy.2010.08.016.

25. Green, M.S. Etherington, J.R., 1977, Oxidation of ferrous iron by rice (Oryza sativa L.) roots: A mechanism for waterlogging tolerance?', Journal of Experimental Biology, 28: 678-690. doi:10.1093/jxb/28.3.678.

26. Halliwell, B., 2006, Reactive species and antioxidants. Redox biology is a fundamental theme of aerobic life, Plant Physiology, 141: 312-22; doi:10.1104/pp.106.077073.

27. Halliwell, B., Gutteridge, J.M., 2015, Free Radicals in biology and medicine, [Oxford, United Kingdom University Press. $5^{\text {th }}$ Edition], doi:10.1093/acprof:oso/9780198717478.001.0001.

28. Heath, R.L., Packer, L., 1968, Photoperoxidation in isolated chloroplasts, Kinetics and stoichiometry of fatty acid peroxidation, Archives of Biochemistry and Biophysics, 125 (1): 189-198. doi:10.1016/00039861(68)90654-1.

29. Hendry, G.A.F., Brocklebank, K.J., 1985, Iron-induced oxygen radical metabolism in waterlogged plants, New Phytologist, 101: 199-213. doi:10.1111/j.1469-8137.1985.tb02826.x.

30. Hodges, D.M., DeLong, J.M., Forney, C.F., Prange, R.K., 1999, Improving the thiobarbituric acid reactive substances assay for estimating lipid peroxidation in plant tissues containing anthocyanin and other interfering compounds, Planta, 207: 604-611. doi:10.1007/s004250050524.

31. Ivanova, D.G., Singh, B.R., 2003, Nondestructive FTIR monitoring of leaf senescence and elicitininduced changes in plant leaves, Biopolymers, 7 2(2): 79-85. doi:10.1002/bip.10297. 
32. Jamme, F., Vindigni, J.-D., Méchin, V., Cherifi, T., Chardot, T., Froissard, M., 2013, Single cell synchrotron FT-IR microspectroscopy reveals a link between neutral lipid and storage carbohydrate fluxes in $S$. cerevisiae, PloS ONE, 8 (9) e74421 doi:10.1371/journal.pone.0074421.

33. Kačuráková, M., Capeka, P., SasinkovaÂ, V., Wellner, N., EbringerovaÂ, A., 2000, FTIR study of plant cell wall model compounds: pectic polysaccharides and hemicelluloses, Carbohydrate Polymers, 43: 195-203. doi:10.1016/S0144-8617(00)00151-X.

34. Kar, M., Mishra, D., 1976, Catalase, Peroxidase and Polyphenol Oxidase Activities during Rice Leaf Senescence, Plant Physiology, 57: 315-319. doi:10.1104/pp.57.2.315.

35. Kobayashi, T., Nishizawa, N. K., 2012, Iron uptake, translocation, and regulation in higher plants', Annual Review of Plant Biology, 63: 131-152. doi:10.1146/annurev-arplant-042811-105522.

36. Landi, M., 2017, Commentary to: "Improving the thiobarbituric acid-reactive-substances assay for estimating lipid peroxidation in plant tissues containing anthocyanin and other interfering compounds" by Hodges et al., Planta (1999) 207:604-611. Planta, 245: 1067 doi:10.1007/s00425-017-2699-3.

37. Li, X., Ma, H., Jia, P., Wang, J., Jia, L., Zhang, T., Yang, Y., Chen, H., Wei, X., 2012, Responses of seedling growth and antioxidant activity to excess iron and copper in Triticum aestivum L', Ecotoxicology and Environmental Safety, 86: 47-53. doi:10.1016/j.ecoenv.2012.09.010.

38. Magnani, L., Gaydou, M., Jean, C.H., 2000, Spectrophotometric measurement of antioxidant properties of flavones and flavonols against superoxide anion', Analytica Chimica Acta, 411: 209-216. doi:10.1016/S0003-2670(00)00717-0.

39. Majerus, V., Bertin, P., Swenden, V., Fortemps, A., Lobreaux, S., Lutts, S., 2007, Organ- dependent responses of the African rice to short-term iron toxicity: ferritin regulation and antioxidative responses, Biologia Plantarum, 51 (2): 303-312. doi:10.1007/s10535-007-0060-6.

40. Marklund, S., Marklund, G., 1974, Involvement of the superoxide anion radical in the autooxidation of pyrogallol and a convenient assay for superoxide dismutase, European Journal of Biochemistry, 47: 469474. doi:10.1111/j.1432-1033.1974.tb03714.x.

41. Marschner, H., 1995, Mineral Nutrition of Higher Plants, $2^{\text {nd }}$ ed, [New York: Academic Press].

42. McCann, M.C., Hammouri, M., Wilson, R., Belton, P., Roberts, K., 1992, Fourier transform infrared microspectroscopy is a new way to look at plant cell walls, Plant Physiology, 100: 1940-1947 doi:10.1104/pp.100.4.1940.

43. Moura, J.C., Bonine, C.A., de Oliveira Fernandes Viana, J., Dornelas, M.C., Mazzafera, P., 2010, Abiotic and biotic stresses and changes in the lignin content and composition in plants, Journal of Integrative Plant Biology, 52 (4): 360-376. doi:10.1111/j.1744-7909.2010.00892.x.

44. Nakamoto, K., 1978, Infrared and Raman spectra of inorganic and coordination compounds, Wiley, New York doi:10.1002/0470027320.s4104.

45. Ott, R.L., Longnecker, M, 2008, An introduction to statistical methods and data analysis, [ $5^{\text {th }}$ ed., Duxbury Press].

46. Pereira, E.G., Oliva, M.A., Rosado-Souza, L., Mendes, G.C., Colares, D.S., Stopatoa, C.H., Almeida, A.M., 2013, Iron excess affects rice photosynthesis through stomatal and non-stomatal limitations, Plant Science, 201-202: 81-92. doi:10.1016/j.plantsci.2012.12.003.

47. Petibois, C., Drogat, B., Bikfalvi, A., Déléris, G., Moenner, M., 2007, Histological mapping of biochemical changes in solid tumors by FT-IR spectral imaging, FEBS Letters. 581 (28):5469-5474. doi:10.1016/j.febslet.2007.10.052.

48. Ponnamperuma, F.N., 1972, The chemistry of submerged soils, Advances in Agronomy, 24: 29-96. doi:10.1016/S0065-2113(08)60633-1.

49. Sahrawat, K.L., 2010, Reducing iron toxicity in lowland rice with tolerant genotypes and plant nutrition, [in: Plant nutrition and abiotic stress tolerance II', Plant stress, United Kingdom: Global Science Books], 4 (2): 70-75.

50. Sahrawat, K.L., Mulbah, C.K., Diatta, S., Delaune, R.D., Patrick Jr, W.H., Singh, B.N., Jones, M.P., 1996, The Role of Tolerant Genotypes and Plant Nutrients in the Management of Iron Toxicity in Lowland Rice, The Journal of Agricultural Science, 126 (2):143-149. doi:10.1017/S002185960007307X.

51. Sinha, S., Gupta, M., Chandra, P., 1997, Oxidative stress induced by iron in Hydrilla verticillata (1.f.) royle: response of antioxidants, Ecotoxicology and Environmental Safety, 38: 286-291. doi:10.1006/eesa.1997.1598. 
52. Stehfest, K., Toepel, J., Wilhelm, C., 2005, The application of micro-FTIR spectroscopy to analyze nutrient stress-related changes in biomass composition of phytoplankton algae, Plant Physiology and Biochemistry, 43: 717-726. doi:10.1016/j.plaphy.2005.07.001.

53. Surewicz, W.K., Mantsch, H.H., Chapman, D., 1993, Determination of Protein Secondary Structure by Fourier Transform Infrared Spectroscopy, [A Critical Assessment. Biochemistry], 32 (2): 389-393. doi:10.1021/bi00053a001.

54. Vansuyt, G., Lopez, F., Inzé, D., Briat, J.F., Fourcroy, P., 1997, Iron triggers a rapid induction of ascorbate peroxidase gene expression in Brassica napus, FEBS Letters, 410: 1195-1200. doi:10.1016/s00145793(97)00587-5.

55. Xing, W., Li, D., Liu, G. 2010, Antioxidative responses of Elodea nuttallii (Planch.) H. St. John to shortterm iron exposure, Plant Physiology and Biochemistry, 48: 873-878. doi:10.1016/j.plaphy.2010.08.006.

56. Yang, J., Yen, H.E., 2002, Early salt stress effects on the changes in chemical composition in leaves of ice plant and Arabidopsis. A Fourier transform infrared spectroscopy study, Plant Physiology, 130: 1032-1042. doi:10.1104/pp.004325.

57. Yoshida, S., Forno, D.A., Cock, J.H., Gomez, K.A., 1976, Laboratory manual for physiological studies of rice, [Los Baños: International Rice Research Institute. Philippines].

58. Zhai, Z., Gayomba, S.R., Jung, H.I., Vimalakumari, N.K., Piñeros, M., Craft, E., Rutzke, M.A., Danku, J., Lahner, B., Punshon, T., Guerinot, M.L., Salt, D.E., Kochian, L.V., Vatamaniuk, O.K. 2014, OPT3 is a phloem-specific iron transporter that is essential for systemic iron signaling and redistribution of iron and cadmium in Arabidopsis, The Plant Cell., 26: 2249-2264. doi:10.1105/tpc.114.123737.

59. Zhong, S.Q., Shi, J.C., Xu, J.M., 2010, Influence of iron plaque on accumulation of lead by yellow flag (Iris pseudacorus L.) grown in artificial Pb-contaminated soil, Journal of Soils and Sediments, 10: 964-970. doi:10.1007/s11368-010-0213-7.

\section{ANALIZA PARAMETRILOR FIZIOLOGICI ŞI SPECTRALI AI DIFERITELOR VARIETĂŢI DE ORYZA SATIVA L. ÎN CONDIŢII DE STRES CAUZAT DE SURPLUS DE FIER}

\section{(Rezumat)}

Toxicitatea feroasă este un stres abiotic ce se manifestă în condiţii de concentraţii crescute de $\mathrm{Fe}^{2+}$ în soluţia solului şi este o problemă bine cunoscută în cultivarea orezului (Oryza sativa L.) în zonele joase. Soiurile de orez diferă foarte mult în ceea ce priveşte toleranţa la excesul de fier. Acest studiu a luat în calcul patru varietăţi de orez, respectiv Dhruba, Sampriti, Dhiren şi Puspa. Obiectivul studiului a fost observarea influenței aplicării unor concentraţii diferite de $\mathrm{Fe}^{2+}$ asupra creşterii, conţinutului de clorofilă şi activităţii enzimatice antioxidante ale acestor soirui de orez. De asemenea, s-a analizat şi reflectivitatea spectrală şi absorbţia diferitelor legături chimice prin spectroscopia în infrarosu transformată Fourier (FTIR) a celor patru varietăţi de orez. Răsadurile de orez de 7 zile au fost tratate cu sulfat feros şi supuse la 100-750 ppm pentru înca 14 zile. Stresul feros a fost folosit pentru a analiza răspunsurile morfologice şi biochimice. În acelaşi timp, părţile rădăcinii şi tulpinii au fost expuse la reflecţia spectrală infrarosie transformată Fourier. Rezultatele au arătat o scădere a creşterii tulpinilor şi conţinutului în clorofilă, la 750 ppm, în cazul tuturor varietăţilor de orez selectate. Dimpotrivă, activitatea catalazei, conţinutul în proteine şi peroxidarea lipidelor a crescut la aceste varietăţi. Totuşi, o creştere a activităţii CAT în soiul Sampriti şi a activităţii SOD în soiul Dhruba a determinat o toleranţă mai mare la stersul feros faţă de celelalte două soiuri studiate. FTIR a evidenţiat benzi abrupte pentru diferitele grupe funcţionale ale compuşilor diferiţi, atât în părţile rădăcinii, cât şi a tulpinii, în cazul tuturor soiurilor studiate. Rezultatele obţinute au evidenţiat că schimbarea expresiei antioxidante şi spectrele FTIR s-au datorat efectului toxic feros în plantele de orez. 